\title{
The Future of International Liquidity and the Role of China
}

\author{
Zheng Jianwen \\ Wuhan University of Technology, Wuhan, China
}

\begin{abstract}
This paper analyzes the consequences of the internationalization of the Chinese renminbi for the global monetary system and its possible ascension to reserve currency status. In an unstable and financially integrated world, governments' precautionary demand for reserve assets is likely to increase. But the world then risks a third crisis of the global reserve system, another re-run of the Triffin paradox, with an ever-growing emerging-world insurance demand loaded onto a small group of ever more strained net debt suppliers. Two ways to avoid this outcome would entail either expanding the supply of credible reserve liquidity to include some large emerging-market providers, or finding ways to manage emerging-market risks so as to moderate the perceived need for insurance, and China would have to loom large in both solutions. This paper analyzes the consequences of the internationalization of the Chinese renminbi for the global monetary system and its possible ascension to reserve currency status. It argues that if the process proves feasible, despite the difficult hurdles along the way, the results of internationalization would be constructive, both for China and the rest of the world. In today's global monetary system, the emergence of the renminbi (along with other developed- and emerging-market currencies) as a potential reserve currency would expand and diversify the supply of reserve assets, enabling central banks to maintain large buffers against financial shocks while allowing the United States to avoid issuing, as now, a large and growing bulk of the world's safe and liquid claims, and thus bearing the burden of an ever-expanding, and ultimately questionable, debt to the rest of the world.
\end{abstract}

Keywords: international liquidity, global monetary, system role of china

\section{Introduction}

The global crisis in 2008 and 2009 revealed the inherent weaknesses of the current international monetary system that contributed to global financial instability and a weak global economy. For emerging economies, which depend heavily on international trade and capital flows for their growth and development, the failure of the current global reserve system in ensuring sufficient international liquidity caused them to suffer from the spillovers of global shocks.

After the collapse of Lehman Brothers in September 2008, emerging economies were hit hard by the speed and severity of the financial shock spillovers from the global economy. As the global credit shortage intensified, economic and financial systems came under increased pressures. Despite the large build-up of foreign exchange reserves over the past decade, severe dollar shortages tested the resilience of their financial systems. As their access to international interbank markets was limited, the cost of borrowing dollars increased sharply. The

Zheng Jianwen, Ph.D. candidate, School of Economics, Wuhan University of Technology.

Correspondence concerning this article should be addressed to Zheng Jianwen, Luo Shi Lu, Hongshan District No. 122, Wuhan City, Hubei province, China. E-mail: wlqdgsz@163.com. 
combination of the rapid financial shock spillover and deteriorating global economic situation made a slow-down of economic growth in emerging countries inevitable.

The use of a dominant country-issued reserve currency such as the US dollar as an international reserve currency heightens the so-called Triffin dilemma (Triffin, 1960). The world's demand for international reserve assets increases with international income and trade. The reserve-issuing country must continue to run balance of payments deficits to meet the growing demand, while surplus countries accumulate reserves, seemingly indefinitely (Bergsten, 2009). The outstanding external debt of the reserve-issuing country would rise without limit, causing at some point investors to lose confidence in the value of reserve assets. There is no ready mechanism forcing surplus countries or the reserve-issuer to make an adjustment to fix the unsustainable systemic imbalance.

In principle, floating exchange rates and well-functioning international capital markets help to reduce the need for reserves. Despite the increasing trend of adopting floating exchange rate systems and capital mobility, however, the demand for reserves has not declined. A sharp rise in the demand for reserves in recent years reflects a motive to self-insure against capital account crises by emerging economies since they cannot borrow at the going interest rate when they need to. Furthermore, high capital mobility provides an additional source of disturbance, heightening the need for reserves. During balance of payments crises, reserves play an important role in lessening output loss (Becker, Jeanne, Mauro, Ostry, \& Ranciere, 2009). Yet, hoarding international reserves is expensive and less efficient in the absence of assertive external debt management policies.

In fact, while the global financial crisis has harmed its economy, there have been lively discussions on the possibility that the crisis could move the China to global center stage. Although its leaders have been quite guarded, many China scholars and policy makers, especially in local media, aspire for a world economic and financial order less dominated by the US and in which the China can play a more influential role. They suggest that the China should actively involve itself in the process of establishing a new world financial order. One proposal is to strengthen the position of the renminbi in bilateral trade and in capital flows as a prelude to its future internationalization. For instance, Ms. Wu Xiaolin, former deputy governor of the People's Bank of China (PBOC), argued in a public forum that the China should broaden and deepen its financial markets, speed up the renminbi convertibility, and create investment channels for holders of renminbi. She expects that the renminbi could become a reserve currency in 20 years.

In March 2009, the PBOC released a statement by its central bank governor, Zhou Xiaochuan, calling for a reform of the international monetary system (Zhou et al., 2009). In particular, Mr. Zhou is promoting the creation of an international reserve currency that is detached from individual country economic conditions and is able to remain stable in the long run. He is advocating the wider use of special drawing rights (SDRs), especially in international trade, commodities pricing, investment, and corporate bookkeeping. Mr. Zhou argues that a super sovereign currency will not have the inherent risks caused by using credit-based national currencies. The Stiglitz Commission also argued for the creation of a new global.

Reserve system based on SDRs. However, a key challenge here is how to make a super-sovereign currency commercially viable. The share of SDR in private markets is almost negligible. With no national constituency to back up its intrinsic value, the SDR is an unlikely candidate (Eichengreen \& Frankel, 1996).

The China seems to support the move to a partial or total switch to a multi-currency reserve system, backstopped by the greater use of SDRs as well as the gradual internationalization of the renminbi (Liow \& Noor, 2010). But internationalizing the renminbi will likely happen as a gradual and drawn-out process. The 
network externality effect suggests that an incumbent international currency will have a natural advantage of maintaining its dominance. It will also take a significant amount of time before the China develops an efficient financial system and removes its exchange and capital controls, No matter how and when it would happen, however, a tripolar monetary system, in which the renminbi plays a greater role, would occur inevitably in line with emergence of a multipolar world.

\section{The Challenge}

On the demand for reserves, we know from a great deal of research, from the last 20 years, and especially the post-2000 era, has seen an explosive growth. Most of this growth has taken the form of demand for international reserves denominated in U.S. dollars, and most has occurred in emerging markets (see Figure 1). Since 1990, the ratio of reserves to GDP in the advanced countries has held steady at about $4 \%$, but the emerging markets' reserve ratio has more than quintupled, rising from $4 \%$ to more than $20 \%$ of GDP. The emerging markets' weight in the world economy has massively increased over that time (and has done so especially quickly since the 2007-2009 crisis), so a composition effect adds impetus to the growth. Since 1990, global holdings of international reserve assets have risen fully 60 -fold, from $\$ 200$ billion to roughly $\$ 12$ trillion.

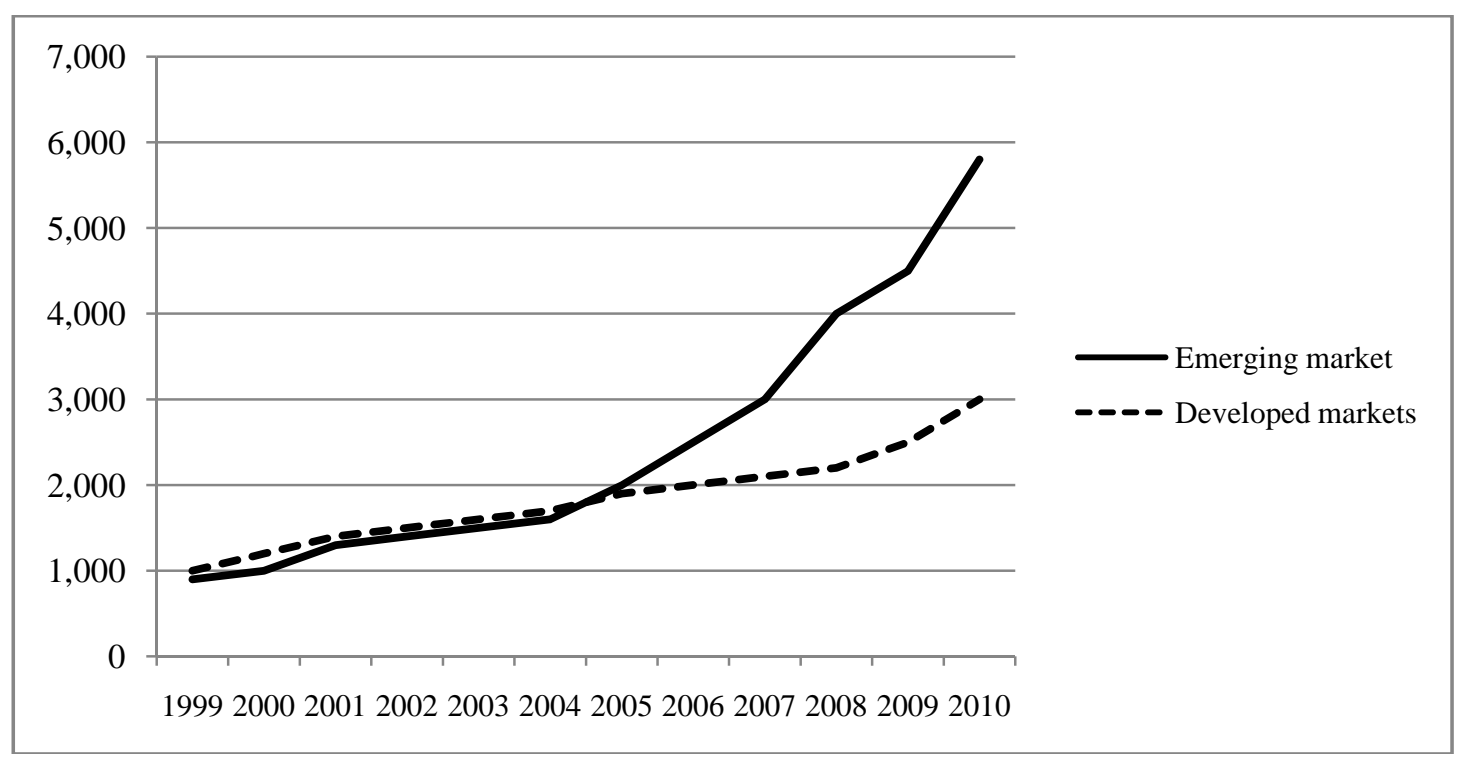

Figure 1. Reserves/GDP in EM and DM economies.

Explaining the motives behind this reserve growth has proved hard. Convention analysis assumed that countries hold reserves to ensure access to a given number of months of imports, or to insure against a drying-up of short-term capital inflows in a "sudden stop" event. But variables, such as the trade balance or even short-term debt, have not changed enough to explain the huge increase in reserves over the past two decades. Instead, recent reserve accumulation seems to have been motivated also by a desire for insurance against capital flight in a world of semi-fixed exchange rates. In particular, three main factors financial openness, domestic financial depth (M2/GDP), and the rigidity of the exchange rate-have conspired to drive up demand for reserves relative to GDP. The worry is that reserve accumulation might continue unabated. There is little sign that emerging economies will give up their "fear of floating" and embrace flexible exchange 
rates. A corollary of a fixed exchange rate, however, is that a country facing pressure for appreciation will have to sell its currency and accumulate foreign exchange reserves in the process. Similarly, a country concerned about future downward pressure on its exchange rate will have to accumulate a war chest of foreign reserves to fight off speculative attacks. Either way, fixed exchange rates result in large reserve accumulation.

Absent reforms emerging economies may continue to fear the risks of volatile capital flows, and even with reforms, change might be slow: countries well on the road to DM status thanks to better records of economic reform, like now-OECD members South Korea and Chile, still maintain large war chests. And it is fair to say that EM economies may have plenty more room in the future for both financial openness and M2 ratios to grow to even higher levels. Yet another reason to expect further rapid reserve accumulation is that reserve-hungry emerging economies will grow faster than the reserve-supplying developed ones-not only for technological and demographic reasons, but because of the possibility that the emerging world itself might expand by gaining new members from the lower tiers of developing countries. Adding all these forces, one arrives at a vision of a potentially nearly endless future demand for reserves, which raises the question of where and how the supply can be provided.

\section{A Brief History of Reserve Currencies}

By the late 1960s, the United States could maintain dollar-gold convertibility only with the help of Germany, which sold gold in London whenever the metal threatened to rise above its permitted \$35-per-ounce level.

In 1971, Nixon succumbed to the inevitable and took the United States off the gold link. The world then entered the next phase, pure fiat reserve currencies plus floating Exchange rates, at least in the developed world. Like the Bretton Woods system, the new arrangement had its own internal logic. Floating exchange rates provided a way of absorbing the effects of cross-border capital flows and reduced the need to maintain exchange-stabilization funds. As a result, the demand for reserves still rose in the 1970s and 1980s, but not precipitately, and not out of line with global growth. The demand for reserves in this period was further limited by the fact that the world economy was still dominated by slower-growing mature countries. And, at least after the Great Inflation of the 1970s, debt and inflation levels were moderate enough that all of the key countries had the fiscal and monetary credibility necessary to sustain the promise of a stable real value that, along with convertibility and legal protection, forms a key condition for reserve currency status.

In sum, the demand for reserves was modest and the supply of reserves was adequate.

Thus did the system muddle through into the 1990s, awaiting the next great transformation, which would bring us to the most recent crisis of the international reserve system.

\section{Back to the Present}

The seeds of this crisis were planted during the 1997-1998 emerging-market turmoil. Having seen financial instability trigger sharp economic contractions, humiliating interactions with the IMF, and even, in the case of Indonesia, political revolution, the rising emerging-market powers like Malaysia, Korea, and China, resorted to massive reserve war chest accumulation to avert a replay of those times. Whatever the social cost of otherwise uninvested savings, the stability benefits of the reserve war chests to governments and their policymakers are not hard to recognize. The emerging economies have emerged out of the backwash from the 2008 Crisis and subsequent Great Recession in the DM world in remarkable shape and quickly headed off on a 
more secure recovery track in 2009-2012, which few would have predicted beforehand. Usually, throughout modern history, a crisis in the DM world has precipitated at least one crisis somewhere in the EM world; not this time. However, even as they provided this vital insurance, the EM war chests exacted a price on the developed world. As the emerging economies accumulated their reserves, they either financed developed-world consumption or investment in more risky assets. High consumption put some developed countries on track to deteriorating solvency, and even the switch to riskier assets exposed developed countries to greater volatility. Both chickens have now come home to roost, with most DM economies facing fiscal constraints and sluggish growth.

Most worryingly, these are very large chickens—much larger than were seen during the collapse of either the gold standard in the 1930s or the Bretton Woods system in the 1970s. In comparison with those early eras, the intertwining of national balance sheets has grown to monumental proportions. As shown in Figure 2, gross asset-to-GDP ratios are now far above anything seen during recorded history. Adding further danger to the mix is the intermediation of much of the world's financial asset and liability linkages through banks whose leverage ratios have grown astronomically compared to known history. Moreover, the process of cross-border financial integration is potentially subject to a worrisome feedback. The larger these balance sheet connections grow, the more vulnerable emerging economies are to a funding crisis. Such vulnerability drives emerging economies to accumulate more reserves, thereby further expanding cross-border balance-sheet linkages further and setting off the next twist in the cycle.

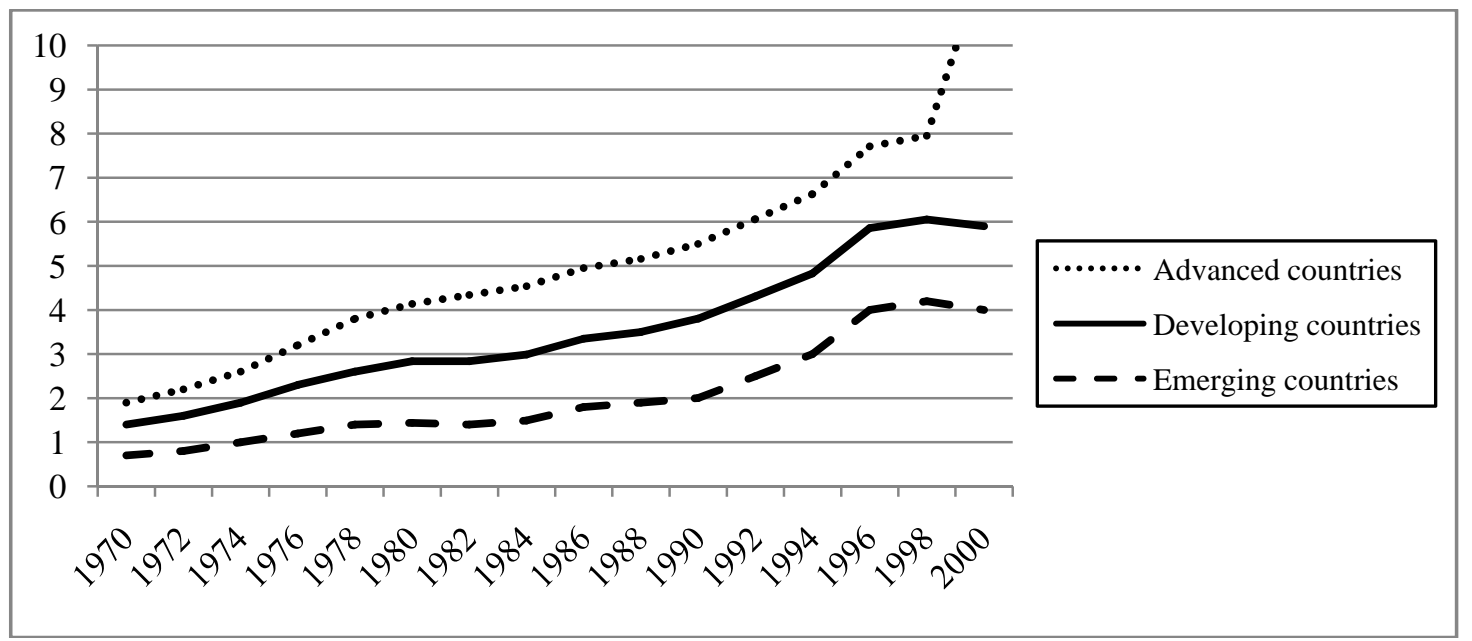

Figure 2. Foreign assets and liabilities.

\section{The Opportunity for China}

China has prospered from its strategy of reserve accumulation and related export surplus. But the strategy has drawbacks. Open-ended reserve accumulation has left China exposed to an eventual devaluation of the dollar. Reliance on exports has left China exposed to a downturn in rich-world consumption-a dependence that proved costly in the crisis of 2008-2009 and may again be a weakness if the euro-zone difficulties deepen. China therefore has an incentive to rethink both halves of its model- to accumulate fewer reserves, on the one hand, and to run a smaller current-account surplus on the other hand. It seems that recent steps—such as faster renminbi appreciation (in part to manage inflation), the shape of the new Five-Year Plan (focusing on domestic demand), and announced shifts in reserve strategy (a slowing down of purchases)—will move China in this 
kind of direction. If so, other emerging economies may well follow. The internationalization of the renminbi could support this shift in strategy. It would allow China to contemplate moving from being a gross (and net) acquirer of reserves, to becoming a gross (and eventually even net) issuer of reserves. From China's perspective, this would reduce exposure to dollar depreciation. From the world's perspective, this would start to move the global economy away from the dangerous asymmetry between developed and emerging markets, and back toward balance in the management of risk and insurance. China's position is such that it has both advantages and disadvantages in achieving this transition to reserve-currency status. Its advantages are the first and foremost scale. China, if it were a reserve currency country, could issue a great deal of safe assets and provide a lot of insurance to those still demanding it. China also has an enviable record of economic growth and stability stretching back two decades. It has a good fiscal position, and is an international net creditor with a good (and improving) sovereign rating. China has also achieved relatively good performance in terms of price stability, at least when one allows for the fact that fast-growing emerging countries are inherently more inflation prone, which tends to force real exchange-rate appreciation. With a willingness to tolerate more nominal exchange rate flexibility, China can moderate those inflation pressures even more. Finally, China is running a number of expanding pilot programs to permit the international use of the renminbi for trade settlement, an offshore currency market to develop in Hong Kong, and some permeability in hitherto tight capital controls that would allow nonresidents to get money in and out.

Even so, we must not get carried away with these signs of progress. The track record or economic reform is short: 20 or 30 years is the blink of an eye when it comes to establishing credibility for reserve-currency purposes. The steps to liberalize the use of the currency across the border are still in their infancy, and much more liberalization would be needed for reserve managers to feel that they have the necessary freedom and security to use the renminbi as a reserve vehicle on a large scale. And to the extent that reserve currencies have historically been associated with economically and politically liberal societies with strong rule of law and property rights, and other institutional quality attributes, it is obvious that China, like almost every other emerging economy, is making progress but still has considerable ground to cover. Most obviously, the simplest proof of progress will come from the data: when China slows down the net acquisition of reserves, we will be in a position to anticipate, a little further down the road, its ability to become a gross or even net issuer of international liquidity, on a small scale at first and then on a larger scale, and thus ultimately play a leading role in resolving the great global asymmetry that bedevils the global monetary system.

\section{Conclusion: What's in It for China and the World}

This paper has focused on the third, and perhaps the most serious, crisis affecting the world's system of international liquidity provision — a crisis that differs from its predecessors 40 and 80 years ago in both scale and scope. Much of the additional danger this time has stemmed from the key asymmetry between the developed and emerging worlds. This facet of the problem was largely absent from the previous great systemic crises, given the relative isolation and minor economic weight of the emerging economies in those times.

Even so, recognizing the nuanced differences, we can still see a common thread in all these crises, a manifestation of the Triffin problem, which sees the problem as one of fiscal limits to reserve supply by ostensibly credible and creditworthy core countries in conditions of asymmetric growth in demand from reserve-accumulating countries. Only this time around, the problem is occurring on a supercharged scale. The global imbalances of the past decade, the ensuing global financial crisis, and the asymmetric recovery in growth 
and sovereign stress are the manifestations of these strains.

The instability of the current system places high responsibilities on policymakers to find a better solution to the problem of international liquidity. There are gains to preserving an open world system of commerce and finance; a shift to global autarky akin to the 1950s would be almost unthinkable and very costly. But the status quo has not been without costs of its own. The stability of the international financial system would be enhanced by shifting to a system that does not load an ever-growing emerging-world insurance demand onto a small group of ever more strained net debt suppliers. That will mean either expanding the supply of insurance in the form of credible reserve liquidity from more developed or ultimately some large emerging-market providers — or finding ways to better pool, share, or otherwise limit the underlying emerging-market risks so as to moderate the perceived need for insurance. History teaches us that previous large shifts in global reserve currency arrangements happened at times of geopolitical conflict, changes in economic leadership, and moments of retreat toward economic autarky. We have to hope that world leaders can do better this time. We have a number of advantages at our disposal today, however, that we did not have before, including an array of mature international institutions (such as the IMF), countries with a demonstrated commitment to cooperate in times of crisis (such as the London G20 summit), and, most importantly, an understanding of macroeconomic policy-making that is different from that constrained by previous systems of thinking.

Given its economic scale, China needs to be a player in this effort to construct a more stable global system, as its asymmetric position alone is a large part of the current imbalance or asymmetry. Given its stated ambition to see its currency internationalize, China seems at least ready to take some steps. But there is a long way to go, and it is fair to ask whether the effort is justified for China. In noneconomic terms, commentators may speak of the geopolitical status that attaches to being a reserve currency country: how it gives a country a "seat at the table”, and may be seen as a badge of global economic leadership. But, to my mind, these purported gains are now the least of it from China's perspective. China is already at the table and is having to take on the responsibilities of leadership. Other more tangible benefits are at stake. If China's currency does attain reserve status it will bring significant economic benefits, starting with the various forms of "exorbitant privilege" that attach to reserve currencies. In the author's own research the author have found that the international status of the U.S. dollar and to some extent the Japanese yen reduced borrowing costs substantially, and to that gain one can add the cost savings and foreign exchange risk mitigation that arise in commerce and finance when transacting in your own currency. Having a reserve currency also benefits a country during periods of distress, given that in times of crisis it is the reserve currencies that attract investors. This safe-haven benefit, a kind of anti-sudden-stop insurance, is arguably at least as important as the income effects of cheap funding.

For these reasons, if China can make the economic, political, and institutional changes needed to support the renminbi as a credible reserve currency, it could be accompanied by a substantial increase in the stability of the global financial system, a gain not only for the world, but also for China.

\section{References}

Adrian, T., \& Shin, H. S. (2008). Liquidity, monetary policy, and financial cycles. Economics and Finance, 36(1), 54-58.

Becker, T., Jeanne, O., Mauro, P., Ostry, J. D., \& Ranciere, R. (2009). IMF Occasional Paper 254-259.

Bergsten, R. N. (2009). Patients' conceptions of the cause of their rheumatoid arthritis: A qualitative study. Musculoskeletal Care, 7(4), 243-255.

Cheung, Y. W., Ma, G., \& McCauley, R. N. (2010). Renminbising China’s foreign assets. Working paper.

Dorucci, E., \& McKay, J. (2011). The international monetary system after the financial crisis. ECB Occasional Paper, 15(30), 
5-13.

Eichengreen, B., \& Frankel, J. (1996). Et maintenant, dans quelle direction aller. Economics and Finance, 1(2), 118-229.

Fratzscher, M., \& Mehl, A. (2011). China’s dominance hypothesis and the emergence of tri-polar global currency system. German

Economic Research, 15, 410-421

Gourinchas, P. O. (2010). US monetary policy, imbalances and the financial crisis. Financial Crisis Inquiry Commission Forum, 24, 25-55

Kenen, P. (2011). Beyond the dollar. Proceedings from the AEA Allied Social Science Association Meetings, Denver, Colorado.

Liow, J., \& Noor, F. A. (2010). Religion and identity in Malaysia, RSIS Commentaries.

Subramanian, A. (2011). Eclipse: Living in the shadow of China's economic dominance. Washington: Peterson Institute for International Economics.

Triffin, R. (1960). Gold and the dollar crisis. New Haven: Yale University Press.

Zhou, Y., Hopper-Borge, E., Shen, T., Huang, X. C., Shi, Z., Kuang, Y. H., ... Chen, Z. S. (2009). Cepharanthine is a potent reversal agent for MRP7 (ABCC10)-mediated multidrug resistance. Biochemical pharmacology, 77(6), 993-1001. 